Original Article

\title{
EFFECT OF BLUMEA LACERA ON TISSUE GSH, LIPID PEROXIDATION AND HEPATIC CELLS IN ETHANOL INDUCED HEPATOTOXICITY IN RATS
}

\section{DEVENDRA S. SHIRODE ${ }^{*}$, ASHISH V. KULKARNI ${ }^{1}$, BRIJENDRA B. JAIN ${ }^{2}$}

1Department of Pharmacology, Dr. D. Y. Patil College of Pharmacy, Akurdi, Pune 411044, ${ }^{2}$ Indrayani Institute of Pharmaceutical Education and Research, Talegaon Dabhade, Pune 410507

Email: dssdypcop@gmail.com

Received: 24 Jun 2015, Revised and Accepted: 25 Oct 2019

ABSTRACT

Objective: To evaluate hepatoprotective effects of ethanol extract of aerial part of Blumea lacera (BLEE) against ethanol-induced hepatotoxicity in rats.

Methods: The in vivo antioxidant activity of BLEE was assessed by determining the tissue glutathione (GSH) and lipid peroxidation (LPO) levels. The BLEE at the doses of 200 and $400 \mathrm{mg} / \mathrm{kg}$ and silymarin $100 \mathrm{mg} / \mathrm{kg}$ administered to the ethanol challenged rats. The effects of BLEE and silymarin on Physical and Biochemical Parameters were measured. Similarly, histopathological changes of the liver were studied.

Results: The BLEE showed in vivo antioxidant activity. A significant $(\mathrm{P}<0.001)$ decrease in SGOT, SGPT, ALP, total and direct bilirubin was observed in BLEE treated group at doses i.e. $200 \mathrm{mg} / \mathrm{kg}$ and $400 \mathrm{mg} / \mathrm{kg}$ as compared to intoxicated group. Liver damage in animal pretreated with BLEE was minimal with distinct preservation of structures and the architectural frame of the hepatic cells.

Conclusion: These findings demonstrated the hepatoprotective effects of BLEE against ethanol-induced liver damage.

Keywords: Blumea lacera, Hepatoprotective, In vivo antioxidant, Ethanol

(C) 2019 The Authors. Published by Innovare Academic Sciences Pvt Ltd. This is an open-access article under the CC BY license (http://creativecommons.org/licenses/by/4.0/] DOI: http://dx.doi.org/10.22159/ijpps.2019v11i12.36453

\section{INTRODUCTION}

Liver is the first and major organ to metabolize all foreign compounds, and it is susceptible to many different diseases [1]. Chronic alcohol intake produces a variety of physiological changes and damages to the liver [2]. At least $80 \%$ of heavy drinkers were reported to develop steatosis, $10-35 \%$ alcoholic hepatitis, and approximately $10 \%$ liver cirrhosis [3]. Jaundice and hepatitis are two major disorders of liver that increase the risk for mortality. Currently, treatment options for hepatotoxicity are very limited [4]. Modern medicine does not so far have fully effective care, particularly for hepatitis [5]. There has been a great deal of interest for the role of complementary and alternative medicines in the treatment of various acute and chronic diseases. Medicinally, natural products have made a significant contribution for the treatment of hepatotoxicity. Our literature survey revealed that the hepatoprotective activity of BLEE was not investigated; hence, these activities have been investigated in the present study.

Blumea lacera is an annual herb traditionally claimed as liver tonic, digestive, anthelmintic, expectorant, antipyretic etc [6-8]. Campesterol has been isolated from aerial parts [9] Recent studies have shown antimicrobial [8], analgesic, hypothermic and tranquilizing activities [9]. Hence the present study was planned to exploit the safety and efficacy of a Blumea lacera for hepatoprotective activity.

\section{MATERIALS AND METHODS}

\section{Plant material and preparation of BLEE}

The aerial parts of Blumea lacera were collected from fields of Sudumbare village, Taluka Maval Pune, Maharashtra during the month of December. It was identified and authenticated (Voucher number 043) by Prof. S. S. Deokule, Dept of Botany, University of Pune, Pune. The aerial parts of plant were shade dried at room temperature and pulverized. The powder obtained was subjected to successive soxhlet extraction with the solvents with increasing order of polarity i. e petroleum ether, chloroform and ethanol. Preliminary phytochemical investigation showed the presence of steroids, flavonoids and saponins in BLEE. Hence, BLEE was selected for the present study.

\section{Chemicals and reagents}

Formalin (Nice), Thiobarbituric acid (TBA) (Loba chemie) Dithiobisnitrobenzoate (DTNB) (Sigma Co.), Trichloroacetic acid (TCA)-(SRL) Disodium hydrogen phosphate (Qualigen), Liquid paraffin (Nice), Silymarin (Micro labs) Chemical Kits-SGOT, SGPT, Total Bilirubin, Direct Bilirubin, ALP (Span diagnostics)

\section{Animals}

Wistar albino rats (150-220 g) and mice (18-25 g) of either sex were used in the study. Approval from the institutional animal ethical committee (1554/PO/a/11/CPCSEA) for the usage of animal during the experiment was obtained as per the Indian CPCSEA guidelines.

Acute toxicity studies

The acute toxicity was determined on albino mice by fixed-dose method of OECD guideline no 420 given by CPCSEA [10].

\section{Experimental designs}

Ethanol-induced hepatotoxicity

Healthy wistar albino rats were divided into 5 groups of 6 animals each.

Group I-served as a normal control group received distilled water ( 5 $\mathrm{ml} / \mathrm{kg}$ body weight, p. o) as a vehicle for $21 \mathrm{~d}$.

Group II-Intoxicated group/ethanol-treated group, received $40 \%$ ethanol ( $2 \mathrm{ml} / \mathrm{g}$ body weight, p. o.) for $21 \mathrm{~d}$.

Group III-standard group/silymarin treated group received silymarin (100 mg/kg body weight, p. o.) and $40 \%$ ethanol (2 $\mathrm{ml} / 100 \mathrm{~g}$ p. o.) for $21 \mathrm{~d}$.

Group IV-BLEE treated group, received BLEE (200 mg/kg body weight, p. o.) and $40 \%$ ethanol ( $2 \mathrm{ml} / 100 \mathrm{~g} \mathrm{p}$. o.) for $21 \mathrm{~d}$.

Group V-BLEE treated group, received BLEE (400 mg/kg body weight, p. o.) and $40 \%$ ethanol ( $2 \mathrm{ml} / \mathrm{g} \mathrm{p}$. o.) for $21 \mathrm{~d}$ [11-13]. 


\section{Biochemical studies}

Blood was obtained from all the animals by puncturing retro-orbital plexus. Collected blood was centrifuged (2000 rpm for $10 \mathrm{~min}$ ) to get clear serum and was used to estimate various biochemical markers like SGPT [14], SGOT [15], ALP [16], Bilirubin (total and direct) [17].

\section{Histopathology}

The liver was excised from the animals and washed with the normal saline. The materials were stored in $10 \%$ buffered neutral formalin and then subjected to histopathological examination.

\section{In vivo tissue GSH estimation}

Tissue Glutathione measurements were performed using a modification of Ellamn procedure [18]. Liver tissue samples were homogenized in ice-cold trichloroacetic acid (1 gm tissue in $10 \mathrm{ml}$ $10 \%$ TCA) in an (Ultra Turrax) tissue homogenizer. The mixture was centrifuged at $3000 \mathrm{rpm}$ for $10 \mathrm{~min}$. Then $0.5 \mathrm{ml}$ of the supernatant was added to $2 \mathrm{ml}$ of $(0.3 \mathrm{M})$ disodium hydrogen phosphate solution. A $0.2 \mathrm{ml}$ solution of dithiobisnitrobenzoate $(0.4 \mathrm{mg} / \mathrm{ml}$ in $1 \%$ sodium acetate) was added, and absorbance was taken at $412 \mathrm{~nm}$.

\section{In vivo lipid peroxidation estimation}

The degree of lipid peroxide formation was assayed by monitoring thiobarbituric reactive substance formation [19]. $1.0 \mathrm{ml}$ of biological sample 0.1-2.0 $\mathrm{mg}$ of membrane protein or 0.1-2.0 $\mu \mathrm{mol}$ of lipid phosphate) was added to $2.0 \mathrm{ml}$ of TCA-TBA-HCL solution and mixed thoroughly. The solution was heated for 1 hour and cooled. Then precipitate was removed by centrifugation at $1000 \mathrm{rpm}$ for $10 \mathrm{~min}$ and absorbance of sample was determined at $535 \mathrm{~nm}$ against a blank that contains all the reagents minus lipid.

\section{Statistical analysis}

Results were expressed as mean \pm SEM $(n=6)$. Statistical analysis was performed with one-way ANOVA followed by the Turkey-Kramer multiple comparisons test. P-value less than 0.05 was considered to be statistically significant $(\mathrm{p}<0.05)$.

\section{RESULTS}

\section{Acute toxicity}

No mortality was observed up to $2000 \mathrm{mg} / \mathrm{kg}$ of dose in mice. Therefore, $1 / 10^{\text {th }}$ and $1 / 5^{\text {th }}(200 \mathrm{mg} / \mathrm{kg}$ and $400 \mathrm{mg} / \mathrm{kg})$ doses were selected.

\section{In vivo tissue GSH and lipid peroxidation}

There was a significant (R0.05) elevation of LPO and depletion of GSH level in the ethanol intoxicated group. Treatment with Silymarin $100 \mathrm{mg} / \mathrm{kg}$ increased tissue GSH level by $31.55 \%$ and decreased tissue LPO level by $53.35 \%$ inhibition. Treatment with BLEE increased the levels of GSH by $17.91 \%$ and $33.42 \%$ at the dose of $200 \mathrm{mg} / \mathrm{kg}$ and $400 \mathrm{mg} / \mathrm{kg}$ respectively (fig. 1). The treatment with BLEE significantly $(\mathrm{P}<0.05)$ reduced the lipid peroxidation by $20.70 \%$ and $51.31 \%$ inhibition at the dose of 200 $\mathrm{mg} / \mathrm{kg}$ and $400 \mathrm{mg} / \mathrm{kg}$ respectively (fig. 2).

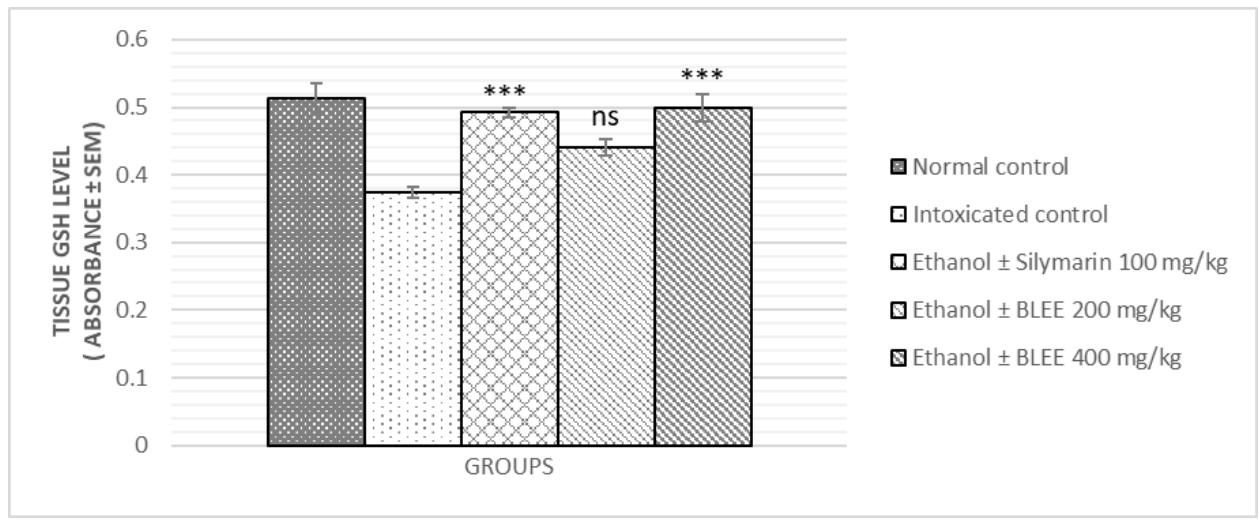

Fig. 1: Effect of BLEE on Tissue GSH level in ethanol induced hepatotoxicity in rats, values are the mean \pm SEM $(n=6)$ of six rats/treatment, significance ${ }^{* * *} \mathrm{P}<0.001,{ }^{* *} \mathrm{P}<0.01,{ }^{*} \mathrm{P}<0.05$, ns $\mathrm{P}>0.05$, compared to ethanol intoxicated

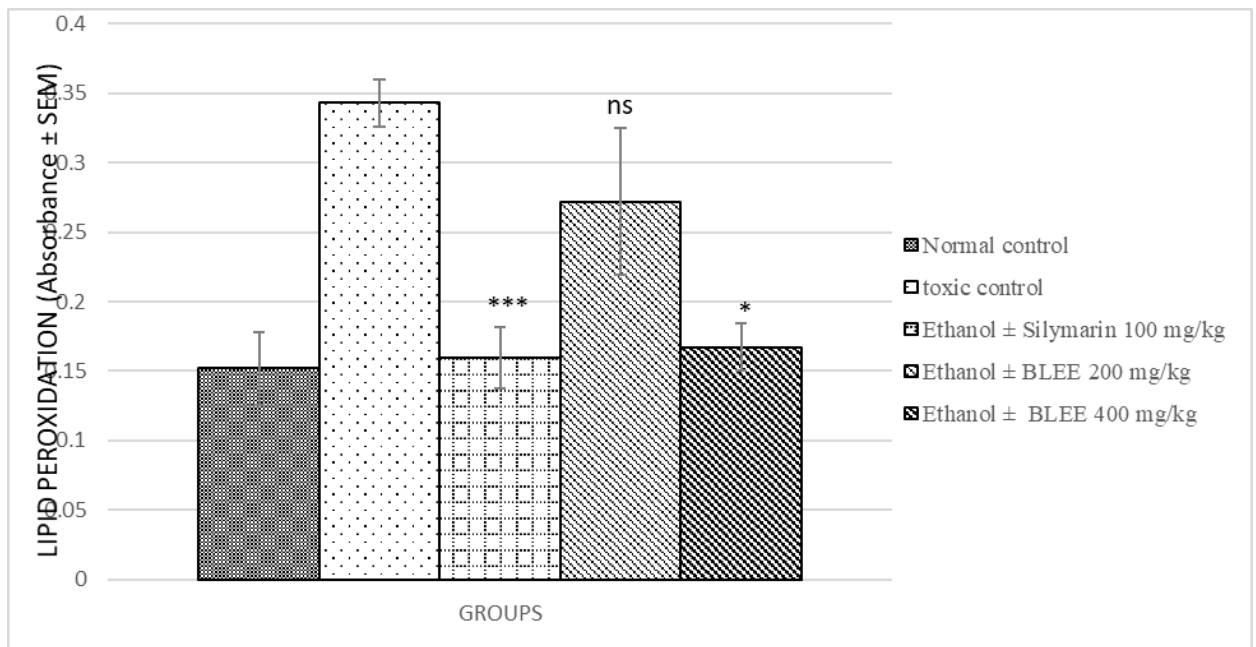

Fig. 2: Effect of BLEE on Lipid peroxidation level in ethanol induced hepatotoxicity, values are the mean \pm SEM $(n=6)$ of six rats/treatment, significance ${ }^{* * *} \mathrm{P}<0.001,{ }^{* *} \mathrm{P}<0.01,{ }^{*} \mathrm{P}<0.05,{ }^{\text {ns }} \mathrm{P}>0.05$, compared to ethanol intoxicated group 


\section{Ethanol-induced hepatotoxicity}

The mean value of serum liver enzymes SGPT, SGOT, ALP and bilirubin (Total and direct) were significantly increased ( $\mathrm{R}<0.05)$ in ethanol intoxicated group as compared to the normal control group. Administration of silymarin (100 mg/kg p. o.) and BLEE (200 mg/kg p. o and $400 \mathrm{mg} / \mathrm{kg}$ p. o.) significantly decreased serum SGPT, SGOT, ALP and bilirubin (Total and direct) levels towards near normal in a dose-dependent manner. (table 1). The groups treated with silymarin and BLEE (dose $400 \mathrm{mg} / \mathrm{kg}$ ) showed significant restoration of liver weight and liver volume nearer to the normal control group (fig. 3 and 4 ).

Table 1: Effect of BLEE on biochemical markers in ethanol-induced hepatotoxicity

\begin{tabular}{|c|c|c|c|c|c|}
\hline \multirow[t]{2}{*}{ Treatment } & \multicolumn{5}{|c|}{ Biochemical parameters (mean \pm SEM) } \\
\hline & $\begin{array}{l}\text { SGOT } \\
\mathrm{U} / 1 \\
\end{array}$ & $\begin{array}{l}\text { SGPT } \\
\mathrm{U} / 1\end{array}$ & $\begin{array}{l}\text { ALP } \\
\text { IU/1 }\end{array}$ & $\begin{array}{l}\text { Total bilirubin } \\
\text { mg/dl }\end{array}$ & $\begin{array}{l}\text { Direct bilirubin } \\
\text { mg/dl }\end{array}$ \\
\hline Normal control & $103.6 \pm$ & $81.83 \pm$ & $119.83 \pm$ & $0.52 \pm$ & $0.256 \pm$ \\
\hline (1 ml dist. Water p. o.) & 11.41 & 9.170 & 12.983 & 0.05 & 0.033 \\
\hline Ethanol (Intoxicated control) & $371.055 \pm$ & $226.5 \pm$ & $242.17 \pm$ & $1.24 \pm$ & $0.702 \pm$ \\
\hline ( $40 \%$ ethanol, $2 \mathrm{ml} / 100$ g p. o) & 12.119 & 19.019 & 19.835 & 0.17 & 0.042 \\
\hline Ethanol+Silymarin & $111.16 \pm$ & $87.83 \pm$ & $124 \pm$ & $0.61 \pm$ & $0.282 \pm$ \\
\hline ( $2 \mathrm{ml} / 100$ g p. o+100 mg/kg. p. o.) & $15.085^{* * *}$ & $9.77^{* * *}$ & $13.42^{* * *}$ & $0.04^{* * *}$ & $0.035^{* * *}$ \\
\hline \multirow[t]{2}{*}{ Ethanol+BLEE (2 ml/100g p. o+200 mg/kg. p. o.) } & $249.33 \pm$ & $91.83 \pm$ & $148.83 \pm$ & $0.71 \pm$ & $0.323 \pm$ \\
\hline & $29.086^{* *}$ & $11.131^{* * *}$ & $13.87^{*}$ & $0.065^{* * *}$ & $0.028^{* * *}$ \\
\hline \multirow[t]{2}{*}{ Ethanol+BLEE ( $2 \mathrm{ml} / 100 \mathrm{~g}$ p. o. $+400 \mathrm{mg} / \mathrm{kg}$. p. o.) } & $125.33 \pm$ & $82.83 \pm$ & $129.16 \pm$ & $0.575 \pm$ & $0.28 \pm$ \\
\hline & $14.266^{* * *}$ & $7.059 * * *$ & $13.07^{* *}$ & $0.04^{* * *}$ & $0.032^{* * *}$ \\
\hline
\end{tabular}

Values are the mean $\pm \operatorname{SEM}(\mathrm{n}=6)$ of six rats/treatment, significance ${ }^{* * *} \mathrm{P}<0.001,{ }^{* *} \mathrm{P}<0.01,{ }^{*} \mathrm{P}<0.05$, ns $\mathrm{P}>0.05$, compared to ethanol intoxicated group

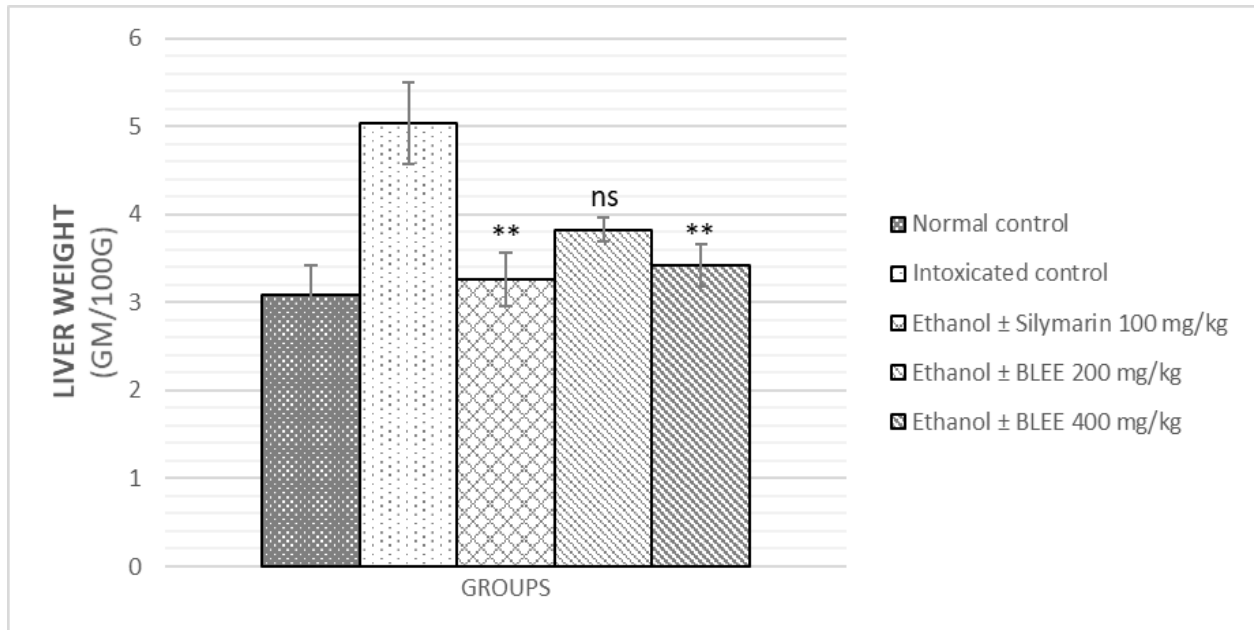

Fig. 3: Effect of BLEE on liver weight level in ethanol-induced hepatotoxicity in rats, values are the mean \pm SEM (n $=6$ ) of six rats/treatment, significance ${ }^{* * *} \mathrm{P}<0.001,{ }^{* *} \mathrm{P}<0.01,{ }^{*} \mathrm{P}<0.05$, ns $\mathrm{P}>0.05$, compared to ethanol intoxicated group

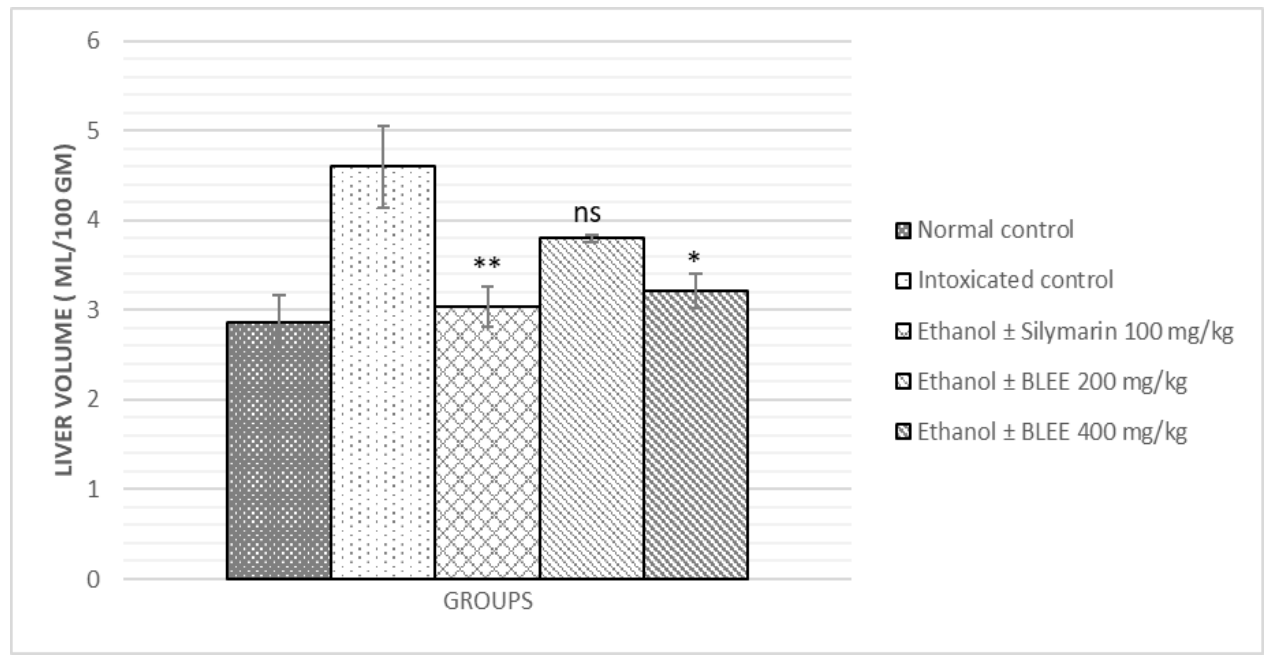

Fig. 4: Effect of BLEE on liver volume level in ethanol induced hepatotoxicity in rats, values are the mean \pm SEM ( $n=6$ ) of six rats/treatment, significance ${ }^{* * *} \mathrm{P}<0.001,{ }^{* *} \mathrm{P}<0.01,{ }^{*} \mathrm{P}<0.05,{ }^{n} \mathrm{P}>0.05$, compared to ethanol intoxicated group 


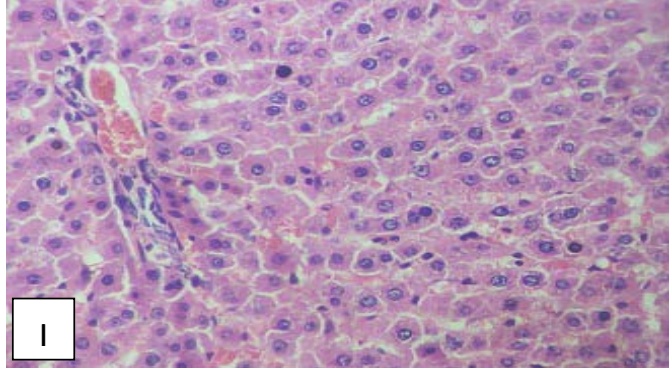

Normal control group showing normal hepatic lobular structure, central vein, portal tract and kupffer cells

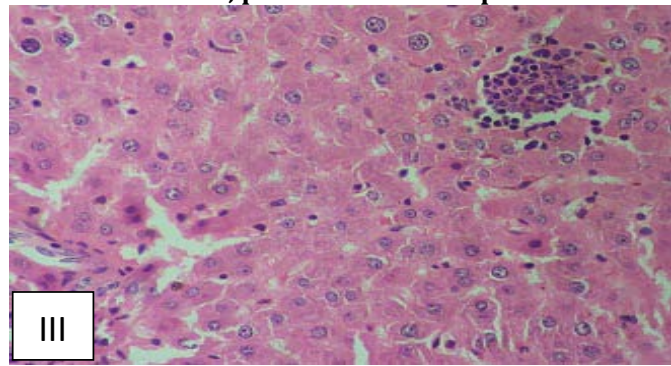

Standard drug group (Ethanol+Std drug $100 \mathrm{mg} / \mathrm{kg}$ silymarin) showing maintained liver architecture, normal Hepatocytes and minimal infiltration of inflammatory cells

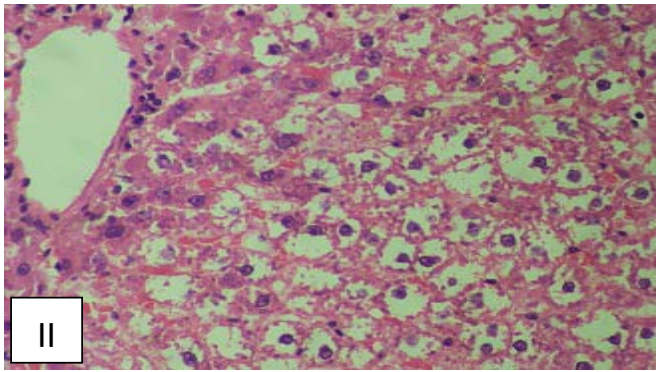

Intoxicated group showing severe hepatocytes degeneration and ballooning. Liver architecture is disturbed

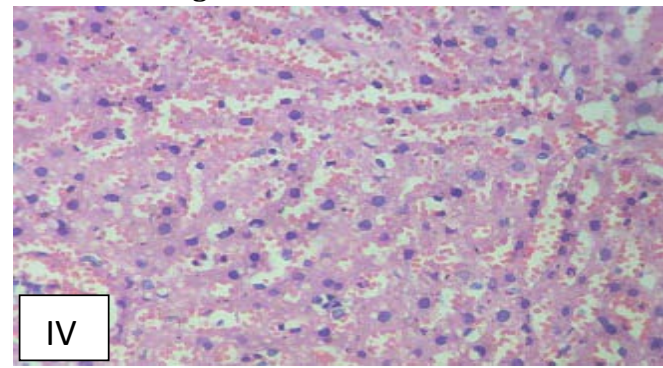

BLEE treated group (Ethanol+BLEE $200 \mathrm{mg} / \mathrm{kg}$ ) showing mild hemorrhages and congestion of sinusoids.

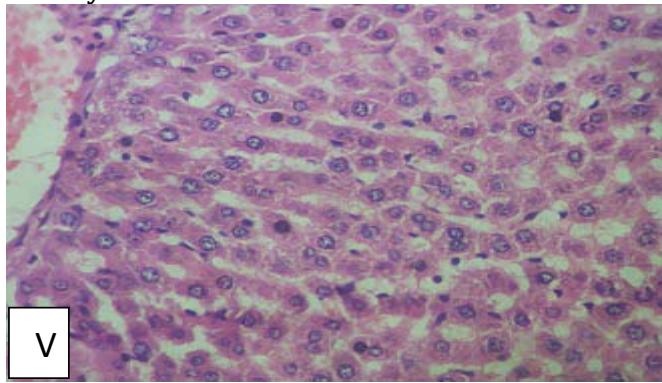

BLEE group (Ethanol+BLEE $400 \mathrm{mg} / \mathrm{kg}$ ) showing normal liver architecture, minimal vacuoles in hepatocytes and normal Sinusoids. (H and $\mathbf{E}$ 40X)

Fig. 5: Histopathological studies

\section{DISCUSSION}

There are many factors, which are responsible for liver damage or injuries such as chemicals and drugs. In the present study, ethanol was used to induce hepatotoxicity. Acute and chronic ethanol administration causes enhanced formation of cytokines, especially TNF- $\alpha$ by hepatic Kupffer cells, which have a significant role in liver injury [20-22]. Ethanol is primarily metabolized by alcohol dehydrogenase with the formation of acetaldehyde. Several other pathways exist: cytochrome P450 dependent microsomal ethanoloxidizing system, catalase and non-enzymatic ethanol oxidation [23] and the involvement of free radical species [24]. Ethanol-induced hepatic hypoxia also has been invoked as a possible cause of the potentiation of hepatotoxicity [11].

The increase as the activity of serum enzymes levels associated with SGPT and SGOT has been observed in ethanol-treated groups, which shows an enhanced permeability, injury and necrosis of hepatocytes [25]. Alkaline phosphatases (ALP) are a family of zinc metalloenzymes. Elevation of ALP and Bilirubin in the intoxicated group indicated the obstructive biliary process. BLEE showed the reduction in levels of SGPT, SGOT, ALP and Bilirubin (total and direct) which indicate improvement in cellular leakage of enzymes and biliary excretion process. These results were also confirmed by physical parameters and histopathological studies (fig. 5).

\section{CONCLUSION}

The present study supports the traditional claims of BLEE by protecting the liver in ethanol-induced liver toxicity. This effect may be due to cytoprotective and antioxidant properties of phytochemicals present such as flavonoids and saponins. Further study is needed to isolate and characterize the phytochemicals responsible for hepatoprotective activity.

\section{ACKNOWLEDGEMENT}

We are thankful to K. M Hospital, Pune, for Histopathological studies. We are also grateful and thankful to Dr. D. Y Patil College of Pharmacy, Akurdi, Pune for providing all the facilities to carry out this research works.

\section{AUTHORS CONTRIBUTIONS}

The Corresponding author, D. S. Shirode performed the experiment and wrote the manuscript. A. V. Kulkarni supported in the laboratory work. B. B. Jain supervised the work and reviewed the manuscript.

\section{CONFLICTS OF INTERESTS}

\section{Declared none}

\section{REFERENCES}

1. Sankar M, Sarkar K, Bhattacharjee R, Chatterjee M, Sil P. Curative role of the aqueous extract of the herb, phyllanthus niruri, against nimesulide induced oxidative stress in murine liver. Biomed Res 2005;16:171-6.

2. Saraswat B, Visen PKS, Patnaik GK, Dhawan BN. Ex vivo and in vivo investigation of picroliv from Picorrhiza kurroa in an alcohol intoxication model in rats. J Ethanopharmacol 1999;66:263-9.

3. Saravaran N, Nalini N. Antioxidant effect of Hemidesmus indicus on ethanol-induced hepatotoxicity in rats. J Med Food 2007;10:675-82. 
4. Modi H, Patel V, Patel K. Hepatoprotective activity of aegle marrmelos against ethanol-induced hepatotoxicity in rats. Asian J Pharm Clin Res 2012;5:164-7.

5. Ansari JA, Sayyed M, Sayyed F. management of non-alcoholic fatty liver disease and their complications. Int J Pharmacol 2011;7:579-88

6. Varier PSV. Indian medicinal plants. Arya Vaidyasala Kottakkal, Orient Longman; 1995. p. 278.

7. Kirtikar KR, Basu BD. Indian medicinal plants. International Book distribution, Dehradun; 2003. p. 1340.

8. Singh B, Singh S, Singh Surendra, Ali L, Mahajan R. Ethanobotanical significance and antimicrobial activity of Blumea lacera. IJPBA 2010;1:314-6.

9. Rastogi RP, Mehrotra BN. Compendium of Indian medicinal plants, CDRI Lucknow and NISC New Delhi; 1999. p. 102.

10. Veeraraghavan P. Expert consultant, CPCSEA, OECD guideline No. 420; 2000.

11. Gulati RK, Agarwal S, Agarwal SS. Hepatoprotective studies on phyllanthus emblica linn and quercetin. Ind J Exp Biol 1995;33:261-8.

12. Kapoor V, Pillai K, Hussain SZ, Balani DK. Hepatoprotective activity of "jigrine" on liver damage caused by alcohol, carbon tetrachloride and paracetamol in rats. Indian J Pharmacol 1994;26:35-40.

13. Sharma A, Sangameswaran B, Jain V, Saluja MS. Hepatoprotective activity of Adina cordifolia against ethanol-induced hepatotoxicity in rats. Int Curr Pharma J 2012;1:279-84.

14. Bradley DW, Maynard JE, Emery G, Webster H. Transminase activity in serum of long term hemolysis patients. Clin Chem 2003; 18:1442.

15. Rej R, Fasce CF, Vanderlinde RE. Increased aspartase aminotransferase activity of serum after in vitro supplymentation with pyridoxal phosphate. Clin Chem 1973;19:92.

16. McComb RB, Bowers GN Jr. Study of optimum buffer conditions for measuring alkaline phosphatase activity in human serum. Clin Chem 1972;18:97.

17. Pearlman PC, Lee RT. Detection of measurement of total Bilirubin in serum with use of surfactants as solubilizing agents. Clin Chem 1974;20:447.

18. Aykae G, Vysal M, Yalein AS, Kocak TN, Sivas A, Oz H. The effect of chronic ethanol ingestion on hepatic lipid peroxide, glutathione, glutathione peroxidase and glutathione transferase in rats. Toxicology 1985;36:71-6.

19. John Buege A, Steven Aust D. Microsomal lipid peroxidation. London: Moury Kleiman Co; 1978. p. 302.

20. Thurman RG. Alcoholic liver injury involves activation of Kupffer cells by endotoxin. Am J Physiol 1998;275:605-11.

21. Tsukamoto H, Takei Y, McClain CJ, Shimizu H, Sato N, Thurman R. How is the liver primed or sensitized for alcoholic liver disease. Alcohol Clin Exp Res 2001;25:171-81.

22. Zhou Z, Wang L, Song Z, Lambert JC, McClain CJ, Kang YJ. A critical involvement of oxidative stress in acute alcoholinduced hepatic TNF-alpha production. Am J Pathol 2003;163:1137-46.

23. Kennedy NY, Tipton KF. Ethanol metabolism and alcoholic liver disease. Essays Biochem 1990;25:137-95.

24. Albano E, Towasi A, Goria GL, Diazani MU. Spin trapping of free radical species produced during the microsomal metabolism of ethanol. Chem Biol Interact 1988;65:223-34.

25. Goldberg DM, Watts C. Serum enzymes changes as evidence of liver reaction to oral alcohol. Gastroenterology 1965;49:256-61. 